\title{
Research on Consumer's Facets of Perceived Risk in Sale Website Platform Buying
}

\author{
Yao CAI, Yi YANG \\ College of Business Guilin University of Electronic Technology, Guangxi Province, China \\ 463760070@qq.com, 741813966@qq.com
}

\begin{abstract}
For the study of consumer's perceived risk in sale website platform buying, the perceived risks of consumers in general e-commerce environment were summarized by literature analysis. And special risks of consumers in sale website platform buying was discovered by interviews with e-commerce experts and sale website platform's members with high degree. The two kinds of risks mentioned above formed the initial items of consumer's perceived risk in sale website platform buying. Through data collection and factor analysis, four perceived risk facets are concluded: Comprehensive service risk, risk of the authenticity of sales products, social risk and financial risk.
\end{abstract}

Index Terms - Perceived risk. The facet of perceived risk. Sale website platform.

\section{Introduction}

With The sale website refers to a platform which sells middle and top-grade brand products with a lower discount. At present, it can be divided into two categories. The first is the sale website which specializes in famous products discount, such as Vipshop and Fclub. The second category is the sale platform which is just a part of the whole website. For example, the Poly-worthwhile as a sale platform is a part of Taobao. The rapid development of Vipshop has attracted the attention of the public. The Vipshop is the most successful sale mode. But other sale platform is unfamiliar with the public. The reasons for this phenomenon are consumers' perceived risk shopping in sale website platform is bigger than shopping in general e-commerce website. So, what kind of risks are consumers concerned when shopping in sale website platform?

\section{Literature Review}

The psychological concept of "perceived risk" is added into consumer behavior research by Bauer for the first time (Bauer, 1960). He believes that purchasing behavior will cause the consequence which is difficult to accurately measure. Therefore the perceived risk is generated ${ }^{[1]}$. Cox (1967) concretes the concept of "perceived risk". He insisted that the risk perceived by consumer in the shopping process included two parts. The first is predicting the probability of adverse consequences caused before buying. The second is the degree of adverse consequences perceived after the purchase [2] Cunningham (1967) bases on the study of Cox, and specifies the perceived risk from two angles: the uncertainty and the consequences. The uncertainty refers to the possibility of negative results for shopping, and the consequence is refers to risk caused by the negative results ${ }^{[3]}$.

The specific content or type of perceived risk is its dimension. Bauer believes that consumer's purchase decision is influenced by perceived risk, but he does no analyze the specific type of the perceived risk ${ }^{[1]}$. Cox (1967) proposes that the consumer's perceived risk in the shopping process included the influence of financial or social psychology ${ }^{[2]}$. Cunningham (1967) suggests that when consumers' purchase target can't meet, the risk of funds, product performance, time and physical losses will get perceived ${ }^{[3]}$. Stone and Gronhaug (1993) point out that the accumulated interpretability of the financial, functional, physical, psychological, social and time risk to the overall risk of perceived is up to $88.8 \%{ }^{[4]}$. Featherman and Pavlou (2003), on the perspective of perceived risk, confirm that the economic, functional, psychological, social, and privacy and the time risk are the six risks facets which are existed in the Internet ${ }^{[5]}$.

\section{The Collection of Risk Factors}

Via querying related literature, 10 perceived risk facets which have studied by the former research scholar are collected. The 18 factors of perceived risk get when shopping in general e-commerce environment. By consulting ecommerce experts and senior sale website member users, 6 special perceived risk factors get when shopping in sale website platform. The 24 risk factors are arranged into the 10 perceived risk facets which collected before, as seen in table 1. 
TABLE 1 Perceived Risk Factors in Sale Website Shopping

\begin{tabular}{|c|c|c|c|c|c|}
\hline Perceived risk facet & \multicolumn{2}{|c|}{ Perceived risk factor } & $\begin{array}{l}\text { Perceived risk facet } \\
\text { Privacy risk }\end{array}$ & \multicolumn{2}{|c|}{ Perceived risk factor } \\
\hline \multirow{2}{*}{ Financial risk } & $\mathrm{R} 1$ & The loss of goods and money & \multirow{2}{*}{ Privacy risk } & R13 & The trace of shopping habits \\
\hline & $\mathrm{R} 2$ & Card information stolen & & R14 & Send preferential message without permission \\
\hline \multirow{3}{*}{ Product risk } & R4 & Fake and defective good & \multirow{3}{*}{ Time risk } & $\mathrm{R} 15$ & $\begin{array}{l}\text { A long time for the browse and search of } \\
\text { product }\end{array}$ \\
\hline & R5 & Old and outdated product style & & R16 & Limited panic buying \\
\hline & $\mathrm{R} 7$ & Limited sale product quantity & & $\mathrm{R} 17$ & $\begin{array}{l}\text { A long time for the return and exchange of } \\
\text { product }\end{array}$ \\
\hline \multirow{3}{*}{ Social risk } & PQ & Friends' objection to shopping in sale & \multirow{3}{*}{ Service risk } & $\mathrm{R} 18$ & Risk of return and exchange product \\
\hline & KO & website platform & & R19 & Maintenance risk \\
\hline & R9 & Oppositions from the family & & $\mathrm{R} 20$ & No online customer service \\
\hline Physical risk & $\mathrm{R} 12$ & Product damage to health & Delivery risk & $\mathrm{R} 24$ & Risk of loss \\
\hline
\end{tabular}

The 24 perceived risk factors, the basic information about consumers' demographic variables and the online shopping behaviors of consumers are formed a questionnaire. Each of the risk elements contained in it is surveyed from two aspects: the possibility of occurrence of a risk and the severity of consequence after risk occurs. A five-point Likert scale is adopted to measure it. At last, according to the results of the pretest and the feedback of the participants, some details are adjusted. And the final questionnaire is formed. The amount of the questionnaire is 210 , and the effective questionnaires are 165. The effective rate was $79 \%$.

From the descriptive statistical analysis, the proportion of men and women who are shopping in the sale website platform close to 1:1. From the perspective of age and educational background, the main consumers of sale website platform are high-educated people. From the angle of monthly income, the middle-low income groups are in the majority who wants to consume high-quality brand product with lower price. The demographic characteristic of the questionnaire is accord with the data of market report, which proves the validity of the sample.

\section{Data Analysis}

\section{A. Project Analysis}

The objective of project analysis is obtaining the value of critical ratio of the 24 perceived risk elements. If elements' critical ratio reaches a significant level $(\mathrm{P}<0.05)$, the elements can be retained, or be removed. After calculation, the following elements' critical ratio does not reach the significant level: R7, R11, R12, R15, R16, R21, and R22. The 7 elements are deleted, and the remained 17 perceived risks elements are composed of a new risk factors table. Through the use of SPSS21.0 to calculate, the value of Kaiser-Meyer-Olkin is 0.885 , and the $\chi 2$ of Bartlett spherical test is 1273.572( $\mathrm{n}=153)$, which reaches a significant level and is suitable for factor analysis. Finally, the results of the rotating factor analysis are shown in Table 2.

After the factor analysis, we conclude four facets of perceived risk that consumers shop in the sale website platform. The accumulated interpretability of the variance reaches $63.278 \%$. The four risks facets are named in turn as comprehensive service risk, risk of the authenticity of sales products, social risk and financial risk.

TABLE 2 Rotated Component Matrix

\begin{tabular}{|c|c|c|c|c|}
\hline \multirow{2}{*}{ Items } & \multicolumn{4}{|c|}{ Perceived risk facets } \\
\cline { 2 - 5 } & 1 & 2 & 3 & 4 \\
\hline R19 & 0.823 & 0.149 & 0.028 & 0.111 \\
\hline R23 & 0.785 & 0.066 & 0.169 & 0.246 \\
\hline R18 & 0.759 & 0.116 & -0.025 & 0.175 \\
\hline R24 & 0.708 & 0.160 & 0.079 & 0.352 \\
\hline R20 & 0.648 & 0.234 & 0.154 & -0.032 \\
\hline R17 & 0.631 & 0.338 & 0.233 & 0.099 \\
\hline R14 & 0.549 & 0.418 & -0.061 & 0.208 \\
\hline R13 & 0.508 & 0.273 & -0.039 & 0.257 \\
\hline R6 & 0.273 & 0.823 & 0.062 & 0.084 \\
\hline R5 & 0.180 & 0.771 & 0.094 & 0.155 \\
\hline R4 & 0.375 & 0.589 & -0.040 & .414 \\
\hline R9 & 0.180 & -0.013 & 0.820 & -0.031 \\
\hline R10 & 0.027 & -0.091 & 0.779 & 0.156 \\
\hline R8 & 0.020 & 0.361 & 0.729 & 0.054 \\
\hline R1 & 0.205 & 0.028 & 0.173 & 0.805 \\
\hline R2 & 0.204 & 0.325 & -0.007 & 0.721 \\
\hline R3 & 0.393 & 0.429 & 0.100 & 0.586 \\
\hline
\end{tabular}




\section{B. Reliability Analysis}

In order to verify the reliability of the measurement, a reliability test is needed. The alpha coefficient between 0.70 and 0.80 is quite good and between 0.80 and 0.90 is very good. And the results by the reliability analysis show that the alpha coefficient of all risk facets is above 0.704, and the alpha coefficient of total scale reaches 0.897 . It is suggested that the risk facets formed eventually are quite good, the analysis results are shown in Table 3.

\section{Validity Analysis}

Validity refers to the degree of object to be accurately measured by using measurement tools, and it can be analyzed from the content and convergent validity. Because, the scale established in this paper is based on predecessors' study whose research results have been verified. Content validity can meet the requirement. And a more rigorous way to test the validity is convergent validity. The average variance of the extracted value (AVE) and the composite reliability (CR) is calculated to measure the convergent validity. When the AVE value of the factor is greater than 0.50 , it is generally believed the factor has good convergent validity. While the composite reliability reflects each element included in the factor, and it is able to explain the latent variables consistently. When the value is higher than 0.70, it shows that the latent variables have a better convergent reliability. Through calculation, the average variance of the extracted value and the composite reliability of the four factors has been shown in table 3, which all meet the requirements. Therefore, the scale has good validity.

TABLE 3 Reliability and Convergent Validity

\begin{tabular}{|l|l|l|l|}
\hline Facets & Alpha & AVE & CR \\
\hline Comprehensive service risk & 0.880 & 0.5686 & 0.8732 \\
\hline $\begin{array}{l}\text { Risk of the authenticity of sales } \\
\text { products }\end{array}$ & 0.781 & 0.5396 & 0.7753 \\
\hline Social risk & 0.704 & 0.6036 & 0.82 \\
\hline Financial risk & 0.704 & 0.5038 & 0.7498 \\
\hline
\end{tabular}

\section{The Establishment of Perceived Risk Facets Shopping in Sale Website Platform}

Through the analysis of the above steps, the four risk facets get by factor analysis is effective. The following detailed instructions and explanations are shown in table 4.
TABLE 4 The Perceived Risk Facets Consumers Shopping in sale website

\begin{tabular}{|c|c|c|c|}
\hline Facet & Amount & Items & Content \\
\hline \multirow{8}{*}{$\begin{array}{l}\text { Comprehensive } \\
\text { service risk }\end{array}$} & \multirow{8}{*}{8} & $\mathrm{R} 13$ & $\begin{array}{l}\text { The trace of shopping } \\
\text { habits }\end{array}$ \\
\hline & & R14 & $\begin{array}{l}\text { Send preferential message } \\
\text { without permission }\end{array}$ \\
\hline & & $\mathrm{R} 17$ & $\begin{array}{l}\text { A long time for the return } \\
\text { and exchange of product }\end{array}$ \\
\hline & & R18 & $\begin{array}{l}\text { The risk of return and } \\
\text { exchange product }\end{array}$ \\
\hline & & R19 & Maintenance risk \\
\hline & & $\mathrm{R} 20$ & $\begin{array}{l}\text { No online customer } \\
\text { service }\end{array}$ \\
\hline & & $\mathrm{R} 23$ & The risk of missing \\
\hline & & $\mathrm{R} 24$ & Loss risk \\
\hline \multirow{3}{*}{$\begin{array}{l}\text { Risk of the } \\
\text { authenticity of sales } \\
\text { products }\end{array}$} & \multirow{3}{*}{3} & $\mathrm{R} 4$ & Fake and defective good \\
\hline & & $\mathrm{R} 5$ & $\begin{array}{l}\text { Old and outdated product } \\
\text { style }\end{array}$ \\
\hline & & R6 & Phony price discount \\
\hline \multirow[t]{3}{*}{ Social risk } & 3 & $\mathrm{R} 8$ & $\begin{array}{l}\text { Friends' objection to } \\
\text { shopping in sale website } \\
\text { platform }\end{array}$ \\
\hline & & R9 & $\begin{array}{l}\text { Oppositions from the } \\
\text { family }\end{array}$ \\
\hline & & $\mathrm{R} 10$ & Psychological pressure \\
\hline \multirow{3}{*}{ Financial risk } & \multirow{3}{*}{3} & $\mathrm{R} 1$ & $\begin{array}{l}\text { The loss of goods and } \\
\text { money }\end{array}$ \\
\hline & & $\mathrm{R} 2$ & Card information stolen \\
\hline & & $\mathrm{R} 3$ & $\begin{array}{l}\text { The cost of return and } \\
\text { exchange }\end{array}$ \\
\hline
\end{tabular}

Comprehensive service risk facet, which is composed of eight elements. Naming is based on the behavior subject of providing service. The number R13 and R20 are the risks of sale website platform providing service. Including leaving their browsing history when shopping on its website which is tracked and sale website does not provide online customer service which caused customers is hard to communicate with merchant in time. R14, R18 and R19 belong to the service risk caused by merchant who serves as a seller. Including sending preferential information to consumers to persistently after complete the transaction, as well as the timely and effective return, exchange and repair service can't be provided in the process of after-sale service. R17, R23 and R24 belong to the service risks of transportation and delivery which are provided by the third party logistics enterprise. Such as the time to delivery, return and exchange goods is long and hard to wait, and the loss may be taken place in these processes.

The risk of the authenticity of sales product, which is composed of the elements of R4, R5 and R6. Sale products are the core product provided by the sale website. First, the products are generally middle and high-end brand product and are sold with a low discount. Consumers may concern whether these products are fake or shoddy. That means the products they offered may not be authentic. Second, because the products sold in sale website platform mostly are inventory, consumers may buy products with old style. Finally, there is no price for comparison, for the brand products sold in sale 
website platform scarcely sold in real shop at the same time. So, the lower discount provided may exist the risk of fake benefits.

Social risk, which is composed of the elements of R8, R9 and R10. Shopping in sale website platform to buy discount brand product will make friends and the family around them hold opposing views on this behavior, and even have negative evaluation of their own, resulting in pressure on themselves. This facet reflects the social relations, so named as social risk.

Financial risk, which is composed of the elements of R1, R2 and R3. This facet intensively reflects the possible loss of goods and money, the loss of bank card stolen and the loss caused by return and exchange goods. These losses belong to the property damage, and thus named as financial risk.

\section{Conclusions and Suggestions}

Through factor analysis, four facets are formed when consumers are shopping in sale website platform. And they are named in turn as comprehensive service risk, risk of the authenticity of sales products, social risk and financial risk. Based on the above data analysis, in order to reduce consumers' perceived risks in sale website platform shopping, some improvement measures can be taken from several aspects, so as to promote the sustainable development of sale website platform. First of all, it is important to establish a positive corporate image and join the authentic alliance.
Providing high-quality and authentic brand product with a lower discount, the perceived risk about the authenticity of sale product will decrease drastically. A third party logistics enterprise with good reputation and good service must be chosen as the cooperative enterprise. For the logistics enterprise providing service to consumers face to face, their service quality can influence consumers' perceived risk. Finally, the persistent and high-quality service should be provided in the entire marketing process, in order to weak consumers' awareness of the risks in the process of shopping in sale website platform.

\section{References}

[1] Bauer, R. A, "Consumer Behavior as Risk taking" in Hancock, R .S. (Ed), Dynamic Marketing for a Changing World, Proceedings of the 43rd Conference of the American Marketing Association, 1960, pp. 389-398.

[2] Cox, D. F (1967), "Risk taking and Information Handling in Consumer Behavior", in Risk Taking and Information Handling in Consumer Behavior, Cox,D.F. eds. Boston: Harvard University Press, 1967, pp.3481.

[3] Cunningham S.M, The Major Dimensions of Perceived Risk, Boston: Harvard University Press, 1967, pp.82-108.

[4] Stone RN, Gronhaug K, "Perceived Risk: Further Considerations for the Marketing Discipline," European Journal of Marketing, 1993, vol. 3, pp. 372-394.

[5] Featherman MS, Pavlou P A, Predicting E-services Adoption: A Perceived Risk Facets Perspective, International Journal of HumanCompute Studies, 2003, vol. 4, pp.451-474. 